\title{
PENGARUH PEMBERIAN EKSTRAK ETANOL DAUN KARAMUNTING (Rhodomyrtus tomentosa (Ait.) Hassk.) TERHADAP KADAR KOLESTEROL DAN TRIGLISERIDA PADA MENCIT PUTIH HIPERLIPIDEMIA
}

\author{
Lucky Novia Anggraeni' ${ }^{\text {; Fakhruddin }}{ }^{2}$; Yogie Irawan $^{3}$ \\ ${ }^{1,2,3}$ STIKES Borneo Cendekia Medika Pangkalan Bun \\ Email korespondensi : luckynovia98@gmail.com
}

\begin{abstract}
ABSTRAK
Pendahuluan: Hiperlipidemia merupakan salah satu faktor risiko dari penyakit kardiovaskular yang disebabkan oleh terbentuknya aterosklerosis pada pembuluh darah. Hiperlipidemia dapat terjadi karena faktor genetik serta gaya hidup yang tidak sehat. Penelitian ini bertujuan untuk mengetahui pengaruh pemberian ekstrak etanol daun karamunting (Rhodomyrtus tomentosa (Ait.) Hassk.) terhadap kadar kolesterol total dan trigliserida pada mencit putih hiperlipidemia.

Metode: Pada penelitian ini menggunakan 20 ekor mencit putih jantan yang terbagi menjadi 5 kelompok mencit hiperlipidemia yaitu kelompok kontrol positif (Simvastatin $0,026 \mathrm{mg} / 20 \mathrm{grBB}$ ), kelompok kontrol negatif (Na CMC 0,5\%) sedangkan kelompok perlakuan ekstrak etanol daun karamunting dosis $14 \mathrm{mg} / 20 \mathrm{grBB}, 28 \mathrm{mg} / 20 \mathrm{grBB}$ dan 56 $\mathrm{mg} / 20 \mathrm{grBB}$. Pengukuran kadar kolesterol total dan trigliserida dilakukan pada hari ke-0, hari ke-14 dan hari ke-28. Presentase penurunan kadar kolesterol total dan trigliserida darah mencit dianalisis menggunakan Uji One Way Anova dan Post Hoc LSD.

Hasil: Berdasarkan hasil uji statistika menyatakan bahwa tidak ada perbedaan signifikan pada penurunan kadar kolesterol total kelompok kontrol positif dengan kelompok perlakuan dosis $56 \mathrm{mg} / 20 \mathrm{grBB}$ dengan nilai signifikan $(\mathrm{p}>0,05)$ dan tidak ada perbedaan signifikan pada penurunan kadar trigliserida kelompok kontrol positif dengan kelompok perlakuan dosis $14 \mathrm{mg} / 20 \mathrm{grBB}, 28 \mathrm{mg} / 20 \mathrm{grBB}$ dan $56 \mathrm{mg} / 20 \mathrm{grBB}$ dengan nilai signifikan $(\mathrm{p}>0,05)$.
\end{abstract}

Kesimpulan: Ekstrak etanol daun karamunting dosis $56 \mathrm{mg} / 20 \mathrm{grBB}$ dapat memberikan penurunan kadar kolesterol total dan trigliserida pada mencit hiperlipidemia.

Kata Kunci : daun karamunting, kolesterol total, trigliserida, hiperlipidemia

\section{ABSTRACK}

Background: Hyperlipidemia is a risk factor for cardiovascular disease caused by the formation of atherosclerosis in blood vessels. It can occur due to genetic factors and an unhealthly lifestyle. This study aimed to determine the effect of giving the ethanol extract of karamunting leaves (Rhodomyrtus tomentosa (Ait.) Hassk.) on total cholesterol and triglyceride levels in hyperlipidemia white mice.

Method: This study used 20 male white mice divided into 5 groups of hyperlipidemia white mice; a positive control group (Simvastatin $0.026 \mathrm{mg} / 20 \mathrm{gBW}$ ), a negative control group (0,5\% $\mathrm{Na} \mathrm{CMC})$, and treatment groups that given the ethanol extract of karamunting leaves at a dose of $14 \mathrm{mg} / 20 \mathrm{gBW}, 28 \mathrm{mg} / 20 \mathrm{gBW}$ and $56 \mathrm{mg} / 20 \mathrm{gBW}$. 
Total cholesterol and triglyceride levels were measured on day 0, day 14 and day 28. The percentage reduction in total cholesterol and triglyceride levels of white mice blood were analyzed using One Way Anova and Post Hoc LSD tests.

Result: Based on the results of the statistical test, it was stated that there was no significant difference in the reduction of total cholesterol level between the positive control group and the treatment group at a dose of $56 \mathrm{mg} / 20 \mathrm{gBW}$ with a significant value ( $p>0.05)$ and there was no significant difference in the reduction of triglyceride level among the positive control group and the treatment groups at a doses of $14 \mathrm{mg} / 20 \mathrm{gBW}, 28$ $\mathrm{mg} / 20 \mathrm{gBW}$ and $56 \mathrm{mg} / 20 \mathrm{gBW}$ with significant values $(P>0.05)$

Conclusion: Ethanol extract of karamunting leaves at a dose of $56 \mathrm{mg} / 20 \mathrm{gBW}$ can reduce the total cholesterol and triglyceride levels in hyperlipidemia white mice.

Keywords: karamunting leaves, total cholesterol, triglycerides, hyperlipidemia

\section{PENDAHULUAN}

Hiperlipidemia merupakan salah satu faktor risiko dari penyakit kardiovaskular yang disebabkan oleh terbentuknya aterosklerosis pada pembuluh darah yang mengakibatkan meningkatnya kejadian penyakit kardiovaskular (WHO, 2016).

Hiperlipidemia adalah suatu kondisi dengan ditandainya jumlah lemak yang berlebih dalam sirkulasi darah (Harikumar et al., 2013). Peningkatan kadar kolesterol total dan LDL yang disertai penurunan HDL akan menyebabkan penimbunan lemak pada lapisan-lapisan pembuluh darah yang berdampak pada terjadinya aterosklerosis. Aterosklerosis yang terjadi pada arteri koroner akan memberikan manifestasi klinis berupa penyakit jantung iskemik yang merupakan salah satu penyebab kematian utama (Pradana et al., 2016).

Karamunting

(Rhodomyrtus tomentosa (Ait.) Hassk.) merupakan salah satu tumbuhan khas kalimantan yang berkhasiat sebagai obat. Tumbuhan karamunting terbukti mengandung beberapa senyawa antara lain flavonoid, tanin, saponin, alkaloid dan triterpenoid. Kadar flavonoid tertinggi terdapat pada ekstrak daun dan buah (Putri, 2015). Secara tradisional daun tumbuhan ini dapat digunakan sebagai antidiabetes (Sinata dan Arifin, 2016), sebagai antibakteri Staphylococcus aureus (Rakhmadhan et al., 2018), sebagai antiinflamasi (Aninditha et al., 2019) dan bunganya dapat digunakan sebagai antikolesterol dan trigliserida (Arief et al., 2012).

Berdasarkan uraian diatas maka perlu dilakukan penelitian untuk membuktikan pengaruh dari pemberian ekstrak etanol daun karamunting (Rhodomyrtus tomentosa (Ait.) Hassk.) terhadap kadar kolesterol total dan trigliserida pada mencit putih hiperlipidemia. Penelitian ini dilakukan untuk mengetahui pengaruh pemberian ekstrak etanol daun karamunting (Rhodomyrtus tomentosa (Ait.) Hassk.) terhadap kadar kolesterol total dan trigliserida pada mencit putih hiperlipidemia yang diinduksi PTU dan pakan tinggi lemak sehingga nantinya dapat dimanfaatkan dan dikembangkan sebagai antihiperkolesterolemia yang berasal dari tumbuhan bagi penderita kolesterol.

\section{METODE PENELITIAN}

\section{Pembuatan simplisia daun karamunting}

Daun karamunting diperoleh dari daerah Pasir Panjang, Kabupaten 
Kotawaringin Barat, Kalimantan Tengah. Pengambilan daun dilakukan pada saat pagi hari atau sore hari. Bagian daun yang diambil adalah bagian daun muda yang masih segar. Daun karamunting yang telah dikumpulkan kemudian dicuci dengan air mengalir untuk menghilangkan kotoran yang melekat pada sampel. Daun yang telah dicuci bersih kemudian ditiriskan, setelah itu daun karamunting dipotong kecil-kecil untuk memperbesar luas permukaan dan mempercepat proses pengeringan. Proses pengeringan daun karamunting dilakukan menggunakan oven dengan suhu $40^{\circ} \mathrm{C}$ selama 24 jam. Setelah itu simplisia diblender dan diayak hingga dihasilkan simplisia dalam bentuk serbuk halus (Purwitasari, 2016).

\section{Ekstraksi daun karamunting}

Sebanyak 1000 gr simplisia kering di blender. Sampel yang telah diblender diekstraksi dengan menggunakan etanol $70 \%$ sebanyak $3000 \mathrm{ml}$ (1:3). Kemudian didiamkan selama 3 hari dalam botol kaca gelap terlindung dari cahaya matahari dan sambil diaduk berulang kali. Ekstrak kemudian disaring dan diuapkan menggunakan waterbath sehingga diperoleh ekstrak berbentuk pasta (Rakhmadhan et al., 2018 ; Kartina et al., 2019).

\section{Skrining fitokimia daun karamunting menggunakan pereaksi kimia dan KLT}

Identifikasi senyawa atau skrining fitokimia dilakukan untuk mengetahui ada tidaknya senyawa aktif yang terdapat pada daun karamunting (Rhodomyrtus tomentosa (Ait.) Hassk). Uji fitokimia menggunakan pereaksi kimia meliputi uji flavonoid, alkaloid, steroid, triterpenoid, fenol, tanin dan saponin (Megawati, 2014; Dwicahmi, 2015; Juniar et al., 2017). Sedangkan identifikasi senyawa atau skrining fitokimia menggunakan kromatografi lapis tipis (KLT) meliputi uji flavonoid dan tanin (Marliana, 2005; Banu dan Nagarajam, 2014).
Uji pengaruh pemberian ekstrak daun karamunting terhadap kadar kolesterol dan trigliserida pada mencit putih hiperlipidemia Pembuatan pakan tinggi lemak

Pakan tinggi lemak tersebut terdiri dari campuran kuning telur puyuh dan minyak babi (Rufaida et al., 2013) yang ditambah dengan minyak jelantah dengan perbandingan 3:2:1. Pemberian diet tinggi lemak ini dilakukan selama 14 hari dan tiap hari diberikan 2 kali sebanyak 0,5 ml. Cara pembuatannya yaitu dengan membuka telur puyuh lalu memisahkan kuning telur dari putih telur, kemudian kuning telur tesebut dicampurkan dengan minyak babi dan minyak jelantah.

\section{Perlakuan hewan uji}

Sebelum diberi perlakuan, mencit (20 ekor) diadaptasikan dahulu dengan keadaan laboratorium selama 7 hari dengan memberikan pakan standar berupa pakan BR-II. Setelah diadaptasi pada hari selanjutnya $\left(\mathrm{T}_{0}\right)$ maka dilakukan analisis kadar kolesterol total terhadap semua hewan uji. Setelah diambil sampel darah dan diketahui kadar kolesterol total dan trigliseridanya maka pada hari itu juga mencit diberi pakan BR-II, diet tingi lemak (campuran kuning telur puyuh dan minyak babi yang ditambah dengan minyak jelantah dengan perbandingan 3:2:1.) dan propiltiourasil $0,01 \%$ agar kadar kolesterolnya meningkat dilakukan selama 14 hari $\left(\mathrm{T}_{1}\right)$. Pada hari ke $14\left(\mathrm{~T}_{2}\right)$ mencit diukur kadar kolesterol total dan trigliseridanya kembali untuk mengetahui seberapa besar peningkatan kadar kolesterol total dan trigliseridanya.

Pada hari ke-14 hingga hari ke-27, kelompok kontrol negatif diberi perlakuan $\mathrm{Na}$ CMC $0,5 \%$, kelompok kontrol positif diberi perlakuan simvastatin 0,026 $\mathrm{mg} / 20 \mathrm{grBB}$, sedangkan kelompok III diberi perlakuan ekstrak etanol daun karamunting dosis $14 \mathrm{mg} / 20 \mathrm{grBB}$, kelompok IV diberi perlakuan dosis 28 $\mathrm{mg} / 20 \mathrm{grBB}$ dan kelompok $\mathrm{V}$ diberi perlakuan dosis $56 \mathrm{mg} / 20 \mathrm{grBB}$. 
Pada hari ke $28\left(\mathrm{~T}_{3}\right)$ semua hewan percobaan diambil darahnya kembali untuk mengetahui seberapa besar penurunan kadar kolesterol total dan trigliseridanya. Darah diambil melalui vena submandibular selanjutnya darah dilakukan penetapan kadar kolesterol total dan trigliseridanya.

\section{Analisis data}

Data hasil kadar kolesterol total dan trigliserida yang diperoleh. Persen penurunan kadar kolesterol total dan trigliserida digunakan untuk mengetahui pengaruh dari ekstrak etanol daun karamunting (Rhodomyrtus tomentosa (Ait.) Hassk).

Data yang diperoleh akan dianalisis dengan pengujian Shapiro-Wilk $(\mathrm{p}>0,05)$ untuk mengetahui data berdistribusi normal atau tidak normal. Hasil uji normalitas ini untuk menentukan analisis berikutnya yaitu analisis parametrik bila terdapat data berdistribusi normal atau non parametrik bila terdapat data berdistribusi tidak normal. Tahap selanjutnya uji homogenitas dengan Levene test $(\mathrm{p}>0,05)$ untuk mengetahui data homogen atau tidak homogen. Tahap selanjutnya uji parametrik menggunakan One way Anova dengan metode $L S D$ untuk mengetahui perbedaan antar kelompok ekstrak etanol daun karamunting, kelompok kontrol positif, dan kelompok kontrol negatif yang diberi perlakuan yang berbeda.

\section{HASIL DAN PEMBAHASAN}

Penelitian ini bertujuan untuk mengetahui pengaruh pemberian ekstrak etanol daun karamunting (Rhodomyrtus tomentosa (Ait.) Hassk.) terhadap kadar kolesterol total dan trigliserida pada mencit putih hiperlipidemia yang diinduksi propiltiourasil dan pakan tinggi lemak.

Daun karamunting dilakukan determinasi untuk menghindari kesalahan penggunaan daun karamunting dalam penelitian. Hasil determinasi oleh laboratorium FMIPA Universitas Lambung Mangkurat menunjukkan bahwa tanaman tersebut adalah daun karamunting (Rhodomyrtus tomentosa (Ait.) Hassk.)

Simplisia daun karamunting diolah menjadi bentuk serbuk dengan tujuan untuk meningkatkan optimalitas proses ekstraksi simplisia daun karamunting. Ukuran serbuk yang kecil akan memperluas kontak antara serbuk dan cairan penyari sehingga diperoleh hasil ekstraksi daun karamunting yang maksimal.

Tabel 1 Hasil Pengeringan Daun Karamunting

\begin{tabular}{c|c|c}
\hline $\begin{array}{c}\text { Bobot basah } \\
\text { (gr) }\end{array}$ & Berat serbuk (gr) & Rendemen (\%) b/b \\
\hline 2500 gram & $585 \mathrm{gr}$ & $58,5 \%$ \\
\hline
\end{tabular}

Dilakukan uji kadar air dengan menggunakan alat Moisture Balance (Salamah et al., 2015). Tujuan pengukuran kadar air adalah untuk memberikan batasan minimal besarnya kandungan air dalam bahan baik ekstrak maupun simplisia. Semakin tinggi kadar air maka semakin mudah untuk ditumbuhi jamur dan kapang sehingga menurunkan aktivitas biologi simplisia dalam masa penyimpanan. Apabila kadar air tidak lebih dari $10 \%$ maka kadar air simplisia tersebut dikatakan memenuhi syarat.

Tabel 2 Susut Pengeringan

\begin{tabular}{c|c|c}
\hline No & Bobot serbuk (gr) & Kadar air (\%) \\
\hline 1 & 1 gram & $6,99 \%$ \\
\hline 2 & 1 gram & $9,08 \%$ \\
\hline 3 & 1 gram & $8,34 \%$ \\
\hline
\end{tabular}

Serbuk daun karamunting diekstraksi dengan metode maserasi menggunakan pelarut etanol $70 \%$ selama 3 hari (Rakhmadhan et al., 2018; Kartina et al., 2019). Etanol adalah penyari yang bersifat universal yaitu dapat melarutkan senyawa polar maupun senyawa nonpolar. Etanol adalah senyawa yang mudah menguap, jernih (tidak berwarna), berbau khas, dan menyebabkan rasa terbakar pada lidah. Etanol mudah menguap baik pada suhu rendah maupun pada suhu mendidih 
(78oC). Bobot jenis etanol tidak lebih dari 0,7964 (Wahyuni, 2015).

Ekstrak etanol daun karamunting yang diperoleh dari hasil penyaringan serbuk seberat 585 gram direndam dalam etanol $70 \%$ sebanyak $3000 \mathrm{ml}$ dan diperoleh rendemen sebesar $37,24 \%$. Selanjutnya ekstrak cair dipekatkan menggunakan waterbath. Penggunaan waterbath bertujuan untuk menguapkan etanol yang terkandung dalam ekstrak cair. Penguapan dilakukan hingga ekstrak berkurang $70 \%$ atau lebih dan didapatkan ekstrak kental sebanyak $100 \mathrm{ml}$.

Tabel 3 Rendemen Ekstrak Etanol Daun

\begin{tabular}{c|c|c}
\multicolumn{3}{c}{ Karamunting } \\
\hline $\begin{array}{c}\text { Serbuk Daun } \\
\text { Karamunting }(\mathrm{gr})\end{array}$ & $\begin{array}{c}\text { Ekstrak Kental } \\
(\mathrm{gr})\end{array}$ & $\begin{array}{c}\text { Rendemen } \\
(\%) \mathrm{b} / \mathrm{b}\end{array}$ \\
\hline $585 \mathrm{gr}$ & $217,9 \mathrm{gr}$ & $37,24 \%$ \\
\hline
\end{tabular}

Tabel 4 Hasil Skrining Fitokimia Daun Karamunting

\begin{tabular}{|c|c|c|c|}
\hline Senyawa & Pereaksi & $\begin{array}{c}\text { Hasil } \\
\text { Identifikasi } \\
\text { Ekstrak }\end{array}$ & Kesimpulan \\
\hline Alkaloid & $\begin{array}{l}\text { Mayer, Wagner, } \\
\text { Dragendroff }\end{array}$ & $\begin{array}{l}\text { Tidak } \\
\text { terbentuk } \\
\text { endapan }\end{array}$ & $(-)$ \\
\hline Flavonoid & $\begin{array}{c}\text { Logam } \\
\text { magnesium }+\mathrm{HCl} \\
\text { pekat }\end{array}$ & $\begin{array}{l}\text { Terbentuk } \\
\text { warna } \\
\text { merah } \\
\text { muda }\end{array}$ & $(+)$ \\
\hline Triterpenoid & $\begin{array}{c}\text { Asam asetat } \\
\text { anhidrat }+\mathrm{H}_{2} \mathrm{SO}_{4}\end{array}$ & $\begin{array}{l}\text { Terbentuk } \\
\text { cincin } \\
\text { kecoklatan }\end{array}$ & $(+)$ \\
\hline Steroid & $\begin{array}{c}\text { Asam asetat } \\
\text { anhidrat }+\mathrm{H}_{2} \mathrm{SO}_{4}\end{array}$ & $\begin{array}{l}\text { Tidak ada } \\
\text { perubahan } \\
\text { warna }\end{array}$ & $(-)$ \\
\hline Fenol & $\mathrm{FeCl}_{3} 1 \%$ & $\begin{array}{c}\text { Terbentuk } \\
\text { warna hijau } \\
\text { kehitaman }\end{array}$ & $(+)$ \\
\hline Tanin & $\begin{array}{c}\text { Gelatin } \\
1 \%+\mathrm{NaCl} 10 \%\end{array}$ & $\begin{array}{l}\text { Terbentuk } \\
\text { endapan } \\
\text { putih }\end{array}$ & $(+)$ \\
\hline Saponin & Aquadest & $\begin{array}{c}\text { Terbentuk } \\
\text { buih lebih } \\
\text { dari } 30 \\
\text { detik }\end{array}$ & $(+)$ \\
\hline
\end{tabular}

Hasil identifikasi atau skrining fitokimia menggunakan pereaksi kimia yang dilakukan menunjukkan bahwa ekstrak daun karamunting positif mengandung flavonoid, triterpenoid, fenol, tanin dan saponin. Sedangkan dari hasil identifikasi menggunakan KLT menunjukkan bahwa terdapat reaksi positif dengan terbentuknya noda berwarna kuning cokelat setelah diuapi ammonia menegaskan adanya kandungan flavonoid dan menghasilkan reaksi positif dengan terbentuknya noda berwarna hitam dengan penampak noda pereaksi $\mathrm{FeCl} 5 \%$ menegaskan adanya kandungan tanin.

\section{Uji Pengaruh Antihiperlipidemia Ekstrak Etanol Daun Karamunting}

Pengujian ekstrak daun

karamunting dilakukan terhadap hewan uji yaitu mencit untuk membuktikan efek antihiperlipidemia. Hewan uji yang digunakan dalam penelitian ini adalah mencit putih jantan sebanyak 20 ekor dengan usia \pm 3 bulan dan berat badan 2030 g. Pengkondisian mencit normal menjadi hiperlipidemia digunakan pakan tinggi lemak selama 14 hari.

Pengambilan darah dilakukan sebelum induksi $(\mathrm{H}-0)$, setelah induksi $(\mathrm{H}-$ 14) dan setelah perlakuan ( $\mathrm{H}-28)$. Pengambilan darah sebelum induksi dilakukan sebagai kadar awal kolesterol total dan trigliserida mencit sehat yang belum terpapar zat penginduksi. Pengambilan darah setelah diinduksi bertujuan untuk mengetahui induksi yang dilakukan berhasil atau tidak dengan membandingkan kadarnya dengan $\mathrm{H}-0$. Pengambilan darah setelah perlakuan bertujuan untuk mengetahui efektivitas ekstrak etanol daun karamunting yang dapat menurunkan kadar kolesterol total dan trigliserida mencit yang telah diinduksi. Darah diambil melalui vena wajah mencit karena sampel yang dibutuhkan cukup besar dan kemungkinan terjadinya hemolisis kecil dibandingkan pengambilan melalui vena ekor. Pengambilan sampel darah dilakukan melalui vena facialis pada daerah submandibular mencit sebanyak 5-10 tetes disetiap pengambilannya.

Hewan uji yang telah dinyatakan hiperlipidemia dikelompokkan menjadi 5 yaitu kelompok kontrol negatif (Na CMC 0,5\%), kelompok kontrol positif (Simvastatin 0,026 mg/20grBB), dan kelompok perlakuan menggunakan ekstrak etanol daun karamunting dosis 14 
$\mathrm{mg} / 20 \mathrm{grBB}, \quad 28 \mathrm{mg} / 20 \mathrm{grBB}$ dan 56 $\mathrm{mg} / 20$ grBB. Pemberian ekstrak etanol daun karamunting, kontrol negatif dan kontrol positif dilakukan selama 14 hari dimulai dari hari ke-14 sampai hari ke-27. Selisih hasil pengukuran kolesterol total dan trigliserida hari ke-28 dan hari ke-14 adalah sebagai persen penurunan kadar kolesterol total dan trigliserida mencit setelah perlakuan.

Berdasarkan pada tabel 5, persen kadar kolesterol total mengalami kenaikan yaitu rata-rata presentase kenaikan kontrol negatif 25,08\%, kontrol positif 23,67\% dan kelompok ekstrak daun karamunting dosis $14 \mathrm{mg} / 20 \mathrm{grBB}, 28 \mathrm{mg} / 20 \mathrm{grBB}$ dan $56 \mathrm{mg} / 20 \mathrm{grBB}$ berturut-turut sebesar $23,77 \%, 23,41 \%$ dan $25,37 \%$ sehingga induksi PTU dan pakan tinggi lemak dikatakan berhasil. Pada kelompok kontrol negatif tidak mengalami penurunan kadar kolesterol total $-2,18 \%$ sedangkan pada kelompok kontrol positif dan kelompok perlakuan ekstrak etanol daun karamunting mengalami penurunan kadar kolesterol total berturut-turut sebesar 34,27\%, $27,88 \%, 26,44 \%$ dan $28,61 \%$ karena mencit yang hiperlipidemia diobati dengan simvastatin pada kontrol positif dan ekstrak etanol daun karamunting pada kelompok perlakuan.

Tabel 5 Rarata Kadar Kolesterol Total $(\mathrm{mg} / \mathrm{dL})$

\begin{tabular}{|c|c|c|c|c|c|}
\hline \multirow[b]{2}{*}{ Kelompok } & \multicolumn{5}{|c|}{ Kadar kolesterol total darah } \\
\hline & $\begin{array}{l}\text { Hari } \\
\text { ke }-0\end{array}$ & $\begin{array}{c}\text { Hari } \\
\text { ke-14 }\end{array}$ & $\begin{array}{c}\% \\
\text { Rerata } \\
\text { Kenaik } \\
\text { an } \\
\end{array}$ & $\begin{array}{c}\text { Hari } \\
\text { ke-28 }\end{array}$ & $\begin{array}{l}\% \text { Rerata } \\
\text { Penurunan }\end{array}$ \\
\hline & $\begin{array}{l}X \pm \\
S D\end{array}$ & $\begin{array}{l}X \pm \\
\text { SD }\end{array}$ & $\begin{array}{l}X \pm \\
\text { SD }\end{array}$ & $\begin{array}{l}X \pm \\
\text { SD }\end{array}$ & $\mathrm{X} \pm \mathrm{SD}$ \\
\hline $\begin{array}{l}\text { Kontrol } \\
\text { negatif } \mathrm{Na} \\
\text { CMC } 0,5 \%\end{array}$ & $\begin{array}{l}123,25 \\
\pm 5,67\end{array}$ & $\begin{array}{l}154,00 \\
\pm 5,09\end{array}$ & $\begin{array}{r}25,08 \\
\pm 5,39\end{array}$ & $\begin{array}{l}157,25 \\
\pm 6,89\end{array}$ & $-2,18 \pm 5,24$ \\
\hline $\begin{array}{l}\text { Kontrol } \\
\text { positif } \\
\text { simvastatin } \\
0,026 \mathrm{mg} / 20 \\
\text { gramBB }\end{array}$ & $\begin{array}{l}120,25 \\
\pm 3,20\end{array}$ & $\begin{array}{l}148,75 \\
\pm 2,98\end{array}$ & $\begin{array}{r}23,67 \\
\pm 2,77\end{array}$ & $\begin{array}{r}97,75 \\
\pm 8,53\end{array}$ & $34,27 \pm 5,80^{\mathrm{a}}$ \\
\hline $\begin{array}{l}\text { Ekstrak } \\
\text { Etanol Daun } \\
\text { Karamunting } \\
\text { dosis } 14 \\
\mathrm{mg} / 20 \\
\text { gramBB }\end{array}$ & $\begin{array}{l}123,25 \\
\pm 6,18\end{array}$ & $\begin{array}{l}152,50 \\
\pm 6,35\end{array}$ & $\begin{array}{r}23,77 \\
\pm 1,49\end{array}$ & $\begin{array}{l}110,00 \\
\pm 6,58\end{array}$ & $27,88 \pm 2,68^{\mathrm{a}}$ \\
\hline $\begin{array}{l}\text { Ekstrak } \\
\text { Etanol Daun } \\
\text { Karamunting } \\
\text { dosis } 28 \\
\mathrm{mg} / 20 \\
\text { gramBB }\end{array}$ & $\begin{array}{c}115,75 \\
\pm \\
11,38\end{array}$ & $\begin{array}{c}142,75 \\
\pm \\
12,81\end{array}$ & $\begin{array}{c}23,41 \\
\pm 1,81\end{array}$ & $\begin{array}{l}104,75 \\
\pm 5,85\end{array}$ & $26,44 \pm 2,56^{\mathrm{a}}$ \\
\hline $\begin{array}{l}\text { Ekstrak } \\
\text { Etanol Daun } \\
\text { Karamunting } \\
\text { dosis } 56 \\
\mathrm{mg} / 20 \\
\text { gramBB }\end{array}$ & $\begin{array}{l}122,75 \\
\pm 7,18\end{array}$ & $\begin{array}{c}154,00 \\
\pm \\
11,80\end{array}$ & $\begin{array}{r}25,37 \\
\pm 3,99\end{array}$ & $\begin{array}{l}109,75 \\
\pm 7,04\end{array}$ & $\begin{array}{c}28,61 \pm \\
3,47^{\mathrm{a}, \mathrm{b}}\end{array}$ \\
\hline
\end{tabular}

\section{Keterangan :}

Hari ke-0 : kadar kolesterol total awal sebelum perlakuan

Hari ke-14 : kadar kolesterol total setelah induksi PTU \& pakan tinggi kolesterol selama 14 hari

Hari ke-28: kadar kolesterol total setelah perlakuan selama 14 hari

a : ada perbedaan signifikan terhadap kontrol negatif dengan uji LSD one way anova

: tidak ada perbedaan signifikan terhadap kontrol positif dengan uji LSD one way anova

Berdasarkan grafik 1 dapat disimpulkan bahwa terjadi penurunan kadar kolesterol total pada semua kelompok hewan uji kecuali kelompok kontrol negatif.

Grafik 1. Rata-rata penurunan kadar kolesterol total

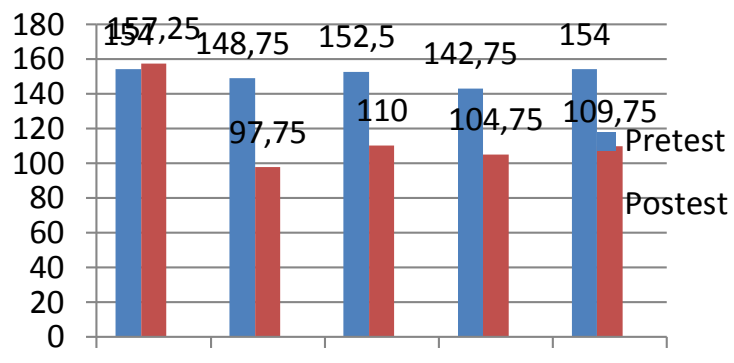

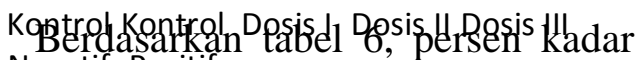
trigliseriđa juga mengalami kenaikan yaitu rata-rata kenaikannya kontrol negatif $60,02 \%$, kontrol positif $62,60 \%$ dan 
kelompok perlakuan ekstrak daun karamunting dosis $14 \mathrm{mg} / 20$ grBB, 28 $\mathrm{mg} / 20$ grBB dan $56 \mathrm{mg} / 20$ gr BB berturutturut sebesar $51,97 \%, 45,82 \%$ dan $44,13 \%$ sehingga induksi pakan tinggi lemak dikatakan berhasil. Sedangkan pada kelompok kontrol negatif, kontrol positif dan kelompok perlakuan ekstrak daun karamunting dosis $14 \mathrm{mg} / 20$ grBB, 28 $\mathrm{mg} / 20$ grBB dan $56 \mathrm{mg} / 20$ gr $\mathrm{BB}$ mengalami penurunan kadar trigliserida berturut-turut sebesar $1,16 \%, 32,86 \%$, $29,43 \%, 31,91 \%$ dan $33,38 \%$.

Tabel 6 Rarata Kadar Trigliserida (mg/dL)

\begin{tabular}{|c|c|c|c|c|c|}
\hline \multirow[b]{2}{*}{ Kelompok } & \multicolumn{5}{|c|}{ Kadar Trigliserida } \\
\hline & $\begin{array}{l}\text { Hari } \\
\text { ke }-0\end{array}$ & $\begin{array}{l}\text { Hari } \\
\text { ke-14 }\end{array}$ & $\begin{array}{l}\% \text { Rerata } \\
\text { Kenaikan }\end{array}$ & $\begin{array}{c}\text { Hari } \\
\text { ke-28 }\end{array}$ & $\begin{array}{c}\% \text { Rerata } \\
\text { Penurunan }\end{array}$ \\
\hline & $\begin{array}{l}X \pm \\
\text { SD }\end{array}$ & $\begin{array}{l}X \pm \\
S D\end{array}$ & $\mathrm{X} \pm \mathrm{SD}$ & $\begin{array}{l}X \pm \\
S D\end{array}$ & $\mathrm{X} \pm \mathrm{SD}$ \\
\hline $\begin{array}{l}\text { Kontrol } \\
\text { negatif } \\
\text { Na CMC } \\
0,5 \%\end{array}$ & $\begin{array}{l}120,50 \\
\pm 8,54\end{array}$ & $\begin{array}{c}191,75 \\
\pm \\
15,52\end{array}$ & $\begin{array}{c}60,02 \pm \\
20,00\end{array}$ & $\begin{array}{c}196,00 \\
\pm \\
15,15\end{array}$ & $1,16 \pm 0,18$ \\
\hline $\begin{array}{l}\text { Kontrol } \\
\text { positif } \\
\text { simvastatin } \\
0,026 \\
\mathrm{mg} / 20 \\
\text { gram BB }\end{array}$ & $\begin{array}{l}119,5 \\
0 \pm \\
10,53\end{array}$ & $\begin{array}{l}193,50 \\
\pm 9,03\end{array}$ & $\begin{array}{c}62,60 \pm \\
11,64\end{array}$ & $\begin{array}{l}129,75 \\
\pm 2,50\end{array}$ & $\begin{array}{c}32,86 \pm \\
2,51^{\mathrm{a}}\end{array}$ \\
\hline $\begin{array}{l}\text { Ekstrak } \\
\text { Etanol } \\
\text { Daun } \\
\text { Karamunti } \\
\text { ng dosis } 14 \\
\mathrm{mg} / 20 \\
\text { gram BB }\end{array}$ & $\begin{array}{l}119,00 \\
\pm 2,16\end{array}$ & $\begin{array}{l}180,75 \\
\pm 6,23\end{array}$ & $\begin{array}{c}51,97 \pm \\
7,42\end{array}$ & $\begin{array}{l}127,50 \\
\pm 3,10\end{array}$ & $\begin{array}{c}29,43 \pm \\
1,67^{\mathrm{a}, \mathrm{b}}\end{array}$ \\
\hline $\begin{array}{l}\text { Ekstrak } \\
\text { Etanol } \\
\text { Daun } \\
\text { Karamunti } \\
\text { ng dosis } 28 \\
\mathrm{mg} / 20 \\
\text { gram BB }\end{array}$ & $\begin{array}{l}123,00 \\
\pm 4,83\end{array}$ & $\begin{array}{c}179,25 \\
\pm \\
12,81\end{array}$ & $\begin{array}{c}45,82 \pm \\
10,44\end{array}$ & $\begin{array}{l}122,00 \\
\pm 8,12\end{array}$ & $\begin{array}{c}31,91 \pm \\
0,90^{\mathrm{a}, \mathrm{b}}\end{array}$ \\
\hline $\begin{array}{l}\text { Ekstrak } \\
\text { Etanol } \\
\text { Daun } \\
\text { Karamunti } \\
\text { ng dosis } 56 \\
\mathrm{mg} / 20 \\
\text { gram BB }\end{array}$ & $\begin{array}{l}117,25 \\
\pm 8,95\end{array}$ & $\begin{array}{c}168,50 \\
\pm \\
15,84\end{array}$ & $\begin{array}{c}44,13 \pm \\
15,18\end{array}$ & $\begin{array}{l}111,50 \\
\pm 1,91\end{array}$ & $\begin{array}{c}33,38 \pm \\
3,11^{\mathrm{a}, \mathrm{b}}\end{array}$ \\
\hline $\begin{array}{l}\text { Keterangan : } \\
\text { Hari ke-0 : k } \\
\text { Hari ke-14 : }\end{array}$ & $\begin{array}{l}\text { adar trigl } \\
\text { kadar } \\
\text { tinggi }\end{array}$ & $\begin{array}{l}\text { iserida as } \\
\text { rigliserid } \\
\text { kolestero }\end{array}$ & $\begin{array}{l}\text { al sebelum } \\
\text { setelah inc } \\
\text { selama } 14 \mathrm{~h}\end{array}$ & $\begin{array}{l}\text { erlakuan } \\
\text { uksi PTL } \\
\text { ri }\end{array}$ & U \& pakan \\
\hline $\begin{array}{l}\text { Hari ke-28: } \\
\text { a } \\
\text { b }\end{array}$ & $\begin{array}{l}\text { kadar tri } \\
\text { ada perl } \\
\text { dengan } \\
\text { : tidak } \\
\text { sitif den }\end{array}$ & $\begin{array}{l}\text { liserida } \\
\text { edaan si } \\
\text { iji } L S D \text { o } \\
\text { da perb } \\
\text { gan uji } L\end{array}$ & $\begin{array}{l}\text { telah perlak } \\
\text { nifikan terh } \\
\text { e way anove } \\
\text { daan signifi } \\
\text { D one way }\end{array}$ & $\begin{array}{l}\text { Ian selan } \\
\text { dap kon } \\
\text { an terha } \\
\text { nova }\end{array}$ & $\begin{array}{l}\text { na } 14 \text { hari } \\
\text { trol negatif } \\
\text { dap kontrol }\end{array}$ \\
\hline
\end{tabular}

Berdasarkan grafik 2 dapat disimpulkan bahwa terjadi penurunan kadar trigliserida pada semua kelompok hewan uji kecuali kelompok kontrol negatif.

Grafik 2. Rata-rata penurunan kadar trigliserida

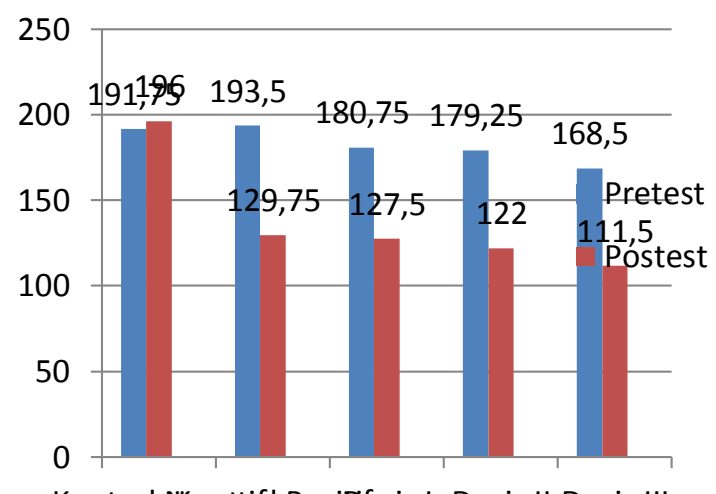

Kontrol NKegattiø| Positf6sis I Dosis II Dosis III

$\mathrm{Na}$ CMC sebagai plasebo dimana tidak mengandung bahan aktif penurun kolesterol. $\mathrm{Na} \mathrm{CMC}$ ini berfungsi mengkondisikan mencit yang hiperlipidemia tanpa diberi pengobatan sebagai pembanding untuk melihat penurunan kadar kolesterol total dan trigliserida setelah perlakuan.

Simvastatin sebagai kontrol positif mempunyai mekanisme yang sama dengan kandungan senyawa aktif yang terdapat pada daun karamunting yaitu flavonoid dan tanin. Flavonoid merupakan kelompok polifenol dan diklasifikasikan berdasarkan struktur kimia serta biosintesisnya (Seleem et al., 2017). Flavonoid mampu memperbaiki fungsi endotel pembuluh darah, dapat mengurangi kepekaan LDL sehingga dapat menurunkan kadar kolesterol total, trigliserida serta meningkatkan HDL dengan menghambat enzim HMG CoA reduktase (Sumardika dan Jawi, 2012). Flavonoid yang berkhasiat sebagai penurun kadar kolesterol total dengan cara menghambat HMG KoA reduktase (Kusuma et al., 2016). Sedangkan tanin merupakan golongan senyawa polifenol yang berperan sebagai antioksidan. Polifenol mampu menurunkan kadar kolesterol dan mampu menghambat pembentukan arterosklerosis. Ada hubungan kemampuan senyawa fenol 
sebagai antioksidan. Senyawa antioksidan seperti polifenol dapat menghambat oksidasi lipid. Senyawa tanin dapat mencegah peningkatan kadar kolesterol melalui mekanisme antioksidan, sehingga dapat meningkatkan mekanisme kolesterol menjadi asam empedu dan meningkatkan ekskresi asam empedu melalui feses. Rendahnya kolesterol dalam hati akan meningkatkan pengambilan kolesterol dari darah ke hati yang selanjutnya berperan sebagai prekursor asam empedu, dengan demikian kadar kolesterol dalam darah akan berkurang (Umarudin et al, 2012). Tanin adalah senyawa aktif yang bersifat polar. Tanin berfungsi sebagai antioksidan, astringent, dan dapat menurunkan kadar kolesterol darah. Tanin dapat larut dalam air dan dalam temperatur yang tinggi dapat mengurangi aktivitas antioksidan yang dimiliki oleh tanin (Hudaya et al, 2015).

\section{KESIMPULAN DAN SARAN}

Dari hasil penelitian diperoleh kesimpulan yaitu pemberian ekstrak daun karamunting (Rhodomyrtus tomentosa (Ait.) Hassk.) pada dosis $56 \mathrm{mg} / 20$ gramBB memiliki pengaruh terhadap penurunan kadar kolesterol total sebesar 28,61 \% dan trigliserida sebesar $33,38 \%$ pada mencit putih hiperlipidemia yang diinduksi PTU dan pakan tinggi lemak.

\section{DAFTAR PUSTAKA}

Anindhita R.R et al. 2019. Uji Aktivitas Antiinflamasi Ekstrak Etanol Daun Karamunting (Rhodomyrtus tomentosa (Aiton) Hassk) Terhadap Tikus Putih Jantan Galur Wistar Yang Diinduksi Karagen. Jurnal Aisyiyah Medika. Vol 4, nomor 3:398

Arief M.I et al. 2012. Pengaruh Bunga Karamunting (Melastoma malabathri.cum L.) Terhadap Kadar Kolesterol Total Dan Trigliserida Pada Tikus Putih Jantan Hiperlipidemia Yang
Diinduksi Propiltiourasil. Prestasi Vol 1, No.2.

Dwicahmi P. 2015. Uji Aktivitas Antibakteri Ekstrak Etanol $70 \%$ Duan Karamunting (Rhodomyrtus tomentosa (Ait.) Hassk.) Terhadap Pertumbuhan Bakteri Vibrio cholerae Secara In Vitro. Fakultas Kedokteran. Universitas Tanjungpura, Pontianak.

Hudaya, T., Alex S., dan Susiana P.S. 2015. Tannin Removal as the Pretreatment of the Multi Stages Extraction of Phaleria macrocarpa Bioactive Compound. Prosiding Seminar Nasional Teknik Kimia "Kejuangan" Pengembangan Teknologi Kimia Pengolahan Sumber Daya Alam Semesta. Yogyakarta. Hal 1-8

Juniar E, et al. 2017. Aktivitas Sitotoksik dan Antioksidan Ekstrak Batang Karamunting (Rhodomyrtus tomentosa (Aiton) Hassk). Program Studi Kimia, Fakultas MIPA, Universitas Tanjungpura.

Kartina et al. 2019. Karakterisasi Kandungan Fitokimia Ekstrak Daun Karamunting (Melastoma malabatchricum L.) Menggunakan Metode Gas Chromatography Mass Spectrometry (GC-MS). Biota Vol.4 (1): 19-22.

Marliana, Soerya Dewi; Venty Suryanti; Suyono. 2005. Skrining Fitokimia dan Analisis Kromatografi Lapis Tipis Komponen Kimia Buah Labu Siam (Sechium edule Jacq. Swartz.) dalam Ekstrak Etanol. Biofarmasi 3 (1):26-31

Megawati et al. 2014. Uji Aktivitas Antifungi Ekstrak Etanol Daun Karamunting (Rhodomyrtus tomentosa (Aiton) Hassk) Terhadap Pertumbuhan Candida albicans Secara In Vitro. Universitas Tanjungpura, Pontianak, Kalimantan Barat

Umaruddin, R. Susanti., A. Yuniastuti. 2012. Efektivitas Ekstrak Tanin 
Seledri Terhadap Kadar Lipid Tikus Putih Hiperkolesterolemia. Unnes Journal of life Science. Vol $1(2)$

Purwitasari, R. 2016. Efek Nefroprotektif Ekstrak Daun Karamunting (Rhodomyrtus tomentosa (Aiton) Hassk.) Terhadap Nefrotoksisitas Yang Diinduksi Asetaminofen. Fakultas Kedokteran. Universitas Tanjungpura, Pontianak.

Putri, A.A., Mulkiya, K., Sadiyah, E.R. 2015. Pengaruh Perbedaan Pelarut Ekstrak Terhadap Kadar Senyawa yang Berpotensi Memiliki Aktivitas Analgesik dari Ekstrak Daun dan Buah Karamunting (Rhodomyrtus tomentosa (Aiton) Hassk.). Prosiding Penelitian SpeSIA. Universitas Islam Bandung : Bandung.

Rakhmadhan N., et al. 2018. Potensi Ekstrak Daun Tanaman Karamunting (Melastoma malabathricum L.) Di Daerah Kalimantan Sebagai Antibakteri Staphylococcus aureus. Jurnal Ilmiah Manuntung, 4(1), 36-40.

Rufaida F, Aulanni'am, Murwani S. 2013. Profil kadar kolesterol total, Low Density Lipoprotein (LDL) dan gambaran histopatologis aorta pada tikus (Rattus norvegicus) hiperkolesterolemia dengan terapi ekstrak air benalu mangga (Dendropthoe pentandra). Student Journal Veterinary School Universitas Brawijaya 3 (2): 1-8

Sinata, Novia \& Arifin Helmi. 2016. Antidiabetes dari Fraksi Air Daun Karamunting (Rhodomyrtus tomentosa (Ait.) Hassk.) Terhadap Kadar Glukosa Darah Mencit Diabetes. Jurnal Sains Farmasi \& Klinis, 3(1);72.
Sumardika, I.W., Kawi, I.M. 2012. Ekstrak Air Daun Ubi Jalar Ungu Memperbaiki Profil Lipid dan Meningkatkan Kadar SOD Darah Tikus Yang Diberi Makanan Tinggi Kolesterol. Medicina. Vol 43 (2):67-70

Wahyuni N. 2015. Formulasi Sediaan Masker Gel dari Ekstrak Etanol Herba Pegagan (Centella asiatica(L)urb) dengan Berbagai Variasi Basis. Fakultas Ilmu Kesehatan. Universitas Islam Negeri Alauddin Makassar 